\title{
L. R. Villermé and Zurich
}

By Erwin H. Ackerknecht

Louis-René Villermé (1782-1863) ${ }^{1}$ started in 1820 (after having served for 10 years as a military surgeon in the Napoleonic wars), working and publishing in public health. He became the probably most eminent member of the group of French hygienists who were then internationally leading the field $^{2}$. In 1835 the Academy of moral and Political sciences charged her members L. R. Villermé and Benoiston de Chateauneuf to do research on the physical and moral situation of the working classes in the departements of France. The two men divided that task. Benoiston de Chateauneuf traveled through the center and the West coast, Villermé in the departements, where most workers were occupied with working cotton, wool and silk.

Villermé published his results in 1840 in his Tableau de l'Etat Physique et Moral des Ouvriers Employés dans les Manufactures de Coton, de Laine et de Soie. This, his best known work, is a classic, which served also as the basis of the French law against child labor of 1841.

Strangely enough this book contains in midst of all the studies of French industrial centers a chapter on the Kanton Zurich and her silk and cotton workers $^{3}$. The picture of the Zurich situation appears compared with that of e.g. Lille or Mulhouse in Villermé's book almost «idyllic».

The Zurich workers are according to Villermé overwhelmingly homeworkers and female and therefore wifes or daughters of peasants ${ }^{4}$. They live mostly in villages around the Zurich lake and participate also in the agricultural work of the husband. There is almost in every house one loom, rarely two. Like in Lyon those called «fabricant» do not produce. They receive orders and have the work done by workers. In 1840 there are about 11000 looms and 16000 individuals who serve them in the Kanton Zurich. Only in Horgen they have two factories, on with 11, the other one with 50 looms $^{5}$. The two insurrections in Lyon in 1831 and 1834, brought a lot of fugitive workers to Zurich, who insisted on using Jacquard machines (also called Lyon loom).

Like the silk industry, the cotton industry in Zurich has been expanding since 1815. There exist also two forms of production: family work or mass 
(factory) work. In the latter, rarer, form the two sexes are mixed, but there are no complaints about obscenities and dissolution as elsewhere ${ }^{6}$. The workday is 12 to 14 hours. Villermé gets very enthusiastic about the cleanliness of the houses, inhabited by the workmen, and the literacy of the population. They are modestly dressed. Compared to the French worker, the Zurich worker in village or city, has more of the sense of order, economy and frugality ${ }^{7}$. The salaries are low, but bearable as the whole family (children included) works and is simultaneously engaged in agriculture, which helps to prevent unemployment in times of crisis. The food is modest. Mostly potatoes, sometimes fish, meat only once per week ${ }^{8}$. The health seems $\operatorname{good}^{9}$. They have saving-banks and mutal assistance associations. They seem satisfied. There is only one pauper in 45 workmen ${ }^{10}$.

Villermé's picture of the other great silk center, Lyon, is far less rosy. There too the «fabricants» do not produce, the work is done by the weavers, the canuts. The relations between the two groups are not good as is obvious from the seditions of 1831 and 1834. The working unit is a chef d'atelier, who owns 2-8 looms, his family and single companions all in one appartment. There exists one big factory with $400-500$ workers, who are well treated ${ }^{12}$. But new factories are under construction. There are in and around Lyon about more than 38000 weavers and unemployment is particularly frequent in this luxury-industry. The sections inhabited by the weavers are very narrow and dark, their quarters extremely dirty ${ }^{13}$. On holidays they wear very elegant clothing. They wear in general shoes all the year round! They are pale and phlegmatic. Their situation improves but they are dissatisfied. They are industrious and relatively sober (Villermé saw but one drunk man in the street) and quiet, «more civilised than many people above the rank of a worker». Their health leaves little to be desired. Their salaries are relatively good. It is significant that many women give their babies in pension in the country because the pensions there are lower than their salaries ${ }^{14}$. The workers eat well, meat almost very day ${ }^{15}$. The workers limit the number of their children to a surprising extent ${ }^{16}$. There is a danger of growing Swiss competition ${ }^{17}$. They have saving banks and mutual help societies.

As Villermé shortly also reports on the cotton situation in Zurich, we bring for comparison an abstract of his report on two French cotton centers: Lille and Mulhouse. Lille (though an old fortress) has a high percentage of workers due to the rapidly expanding cotton industry (one industrial worker in 4,34 inhabitants) ${ }^{18}$. But she is probably also the worst of the cotton places 
in France. 163453 inhabitants, that is one sixth of the population are paupers that is receive public support ${ }^{19}$. Alcoholism (mostly Gin) is extremly widespread in the working population. Their housing, mostly caves, or garrets, is worse than in the worst section of Paris! Villermé never saw worse conditions ${ }^{20}$, than in certain sections of Lille. The workday was 15 hours. The salaries such that the father of an average family made only $450 \mathrm{~F}$ per year. Food was modest. Only the best salaried had boiled meat once a week, on Sunday. In spite of these conditions the workmen did not complain ${ }^{21}$. They had relatively numerous mutual help associations, which unfortunately were connected with bars, and therefore not very efficient. The gin addiction of the Lille worker is already complained of in $1698^{22}$ !

Nearby Roubaix, which was a village not so long ago, is considerably better off. The workers have there good housing, mostly small houses. The introduction of large factories demoralises here too ${ }^{23}$. The workday is here 15 hours too. But the workers are well dressed, none barefoot(!), eat meat daily. The salaries are sufficient. Their health is considerably better than that of the Lille workers. Their mutual help societies do not meet in bars ${ }^{24}$.

Mulhouse is the biggest cotton center in France. No less than 100000 workers. That is $1 / 4$ of the population of the Departement Haut-Rhin work for this industry. Everywhere new houses and new factory buildings are erected. In the large factories the sexes are mixed with the corresponding demoralisation 24 a. The workday is at least 15 hours, in times of crisis, of course, less ${ }^{25}$. As many workers can not afford decent city houses, they live in villages at a mile distance or more, or in very poor accomodation in town. The children are particularly sicklish. The life expectancy is 2 years with half of the workers, 29 with half of the wealthly ${ }^{26}$. Some workers dress very fancy on Sunday, many very miserably every day. Alcoholism is widespread, but less frequent than in the North ${ }^{27}$. The children do not receive a primary education except in some factories where the progressive owners have instituted schools ${ }^{28}$. The salaries are «pretty feable». The poor workers eat the usual potatoes, meat only twice per month ${ }^{29}$. Even the people who earn more, have not the habit to save for their old days. A high percentage of the workers are foreigners (Germans, Swiss, Lorrains). Those born in the country work at home and are better off ${ }^{30}$. The number of children is well above the French average. One of the progressive industrialists of Mulhouse, her mayor A. Koechlin, has built for his workers decent and cheap appartments ${ }^{31}$. His example has been followed. Several factories hold a doctor to the diposal of their workers or encourage mutual help fonds. In those factories they can 
also afford umbrellas in going to work on rainy days, a luxury absent in most other places!

In spite of all the horrors that he has truthfully described, Villermé claims at the end of his book, that the conditions of the industrial workers are better, compared to the agricultural labourer, than ever, and have considerably improved even during the last 20 years ${ }^{32}$. What he is afraid of is the spread of the large factories ${ }^{33}$. As a realist, he does not claim just a series of reforms, but concentrates first on an immediate law to limit the working time of children ${ }^{33}$ a which he obtained and came in Switzerland in 1853 . He ends with a call to the industrialists to establish in their own interest better relations to their workers, presenting a Dr.Auzias of St-Aubin as an example ${ }^{34}$.

Two questions arise in connection with Villermé's Zurich study, especially for those living today in Zurich. The first is: why did Villermé study of all Swiss industrial cities just Zurich? His main reason cannot have been the proximity to Mulhouse (that he had to study), because there would have been other industrial Swiss places just as close. It seems to me very probable that he went to Zurich as one of the most important silk producing places and feared by the French as serious competition to Lyon. He discusses this danger rather extensively ${ }^{35}$. A third reason might have been that his book was, of course, not purely scientific, but had also pedagogic goals. With all his critical attitude towards inhumanities in capitalism and honest descriptions thereof, he believed in capitalism and industry as progressive. A description of «idyllic» Zurich could serve him as a proof that industry was not necessarily a horror, to be abolished and as an appeal for reforms to the capitalists and to the general public (including workmen in so far they could read!).

The second question, which arises is in how far corresponds Villermé's description to reality? Do we deal here with a probably even unintentional deformation of reality for pedagogic reasons like Tacitus Germania? This question is very difficult to answer. My doubts appeared when I read that he did not know German ${ }^{36}$ and could therefore not apply his tried method of directly communicating with the workmen (and women) in their houses, bars, factory etc.! I am not the only one to have uttered such doubts, like e. g. E.Gruner ${ }^{37}$. We must also not forget that the romantic 18th century enthusiasm for Switzerland and preasants was still abroad. A classic example of this is Goethe. How far his description of the Zurich silk industry in his «Wilhelm Meister» is realistic ${ }^{37}$ a? 
There seems little doubt that Zurich was indeed superior to other places in several fields. The workday was shorter in general, the relations with the fabricant, the housing, the shoes, the literacy of the workers, the sense of economy, the sense of satisfaction better! The percentage of paupers, an objective criterion, much lower!

But why was there the demand of abolition of the mechanic looms at the «Ustertag» in 1830, why the sedition and burning of the factory of Korrodi and Pfister in Uster on Nov.22, 1832? Unfortunately there is very little contemporary critical material on this problem. The most extensive are probably the articles of J.Treichler in the "Usterbote» of 1845, and its successor the «Allgemeine Not- und Hilfsblatt» ${ }^{38}$. But Treichler concentrates on child labor which was bad enough, but no worse in Zurich ${ }^{38}$ a then elsewhere.

There seem to be several geographical factors, which favored the absence of certain defects in Swiss industry. One of them is the general use of water power which decentralised automatically Swiss industry for a long time ${ }^{39}$ (nobody has by the way yet explained the miracle why an industry could develop at all in Switzerland in the center of the continent and so far from any raw materials and ports!). The mountainous character of the soil also made the erection of large facturybuildings for a long time very difficult. Another factor of decentralisation! The same mountainous formation, for instance on the very steep slopes of the left bank of the Zurich lake, produced a kind of agriculture (e.g. no possibility to raise grain) where the peasants needed additional sources of income and thus provided a labour reservoir for (home) industry. An important factor of decentralisation was also the absence of raw materials like coal or ore, around which in other countries almost immediately large industrial cities formed.

The silk industry was old in Zurich, flourishing in the 14th century, stimulated in the 16th century by the exiled Locarno protestants, and in the 17 th century by the Huguenots. It spread out of the city, relatively late (end of the 18th century) ${ }^{40}$. At this time also under the pressure of English competition, the handloom begun only slowly to be replaced by weaving and spinning machines ${ }^{41}$. This situation is also reflected in Villmermé's report. Villermé made his survey at a moment where there was a happy equilibrium in the situation of the silk worker. Villermé, who abhorred the large factory and thought the family based homework combined with small agriculture a far better solution, saw and feared the danger of the replacement of the latter by the former for profit reasons ${ }^{42}$. The use of new energy sources (first steam, 
then electricity) tended to further this development. In principle he was right.

And yet perusal of the Monograph «Hausindustrie in der Schweizer Seidenindustrie» (Bern 1904) of Josephine van Anrooy reveals a surprisingly slow advance of this inexorable development. The first weaving machines appeared only in the early 1850 -ies. And according to J. Lorenz in 1871 still $89 \%$ of the looms were handserved (in $190617 \%)^{44}$. Though there existed early some larger enterprises in the country like that of $\mathrm{H}$. Zeller in Balgrist, who controled after 1805700 of the Zurich looms ${ }^{45}$, the small, rural, scattered enterprise within the manufacture («Verlags») system predominated still decades after Villermé ${ }^{46}$. Gerhard Hauptmann had the idea of writing his «Weber» when listening as a student in 1888 to the noises of the Zurich handlooms.

Anrooy quotes Fridolin Schuler ${ }^{47}$ calling silk weaving the least health endangering industrial activity ${ }^{48}$. She describes the housing as satisfactory, nutrition as lacking desirable meat and milk. She is agreably surprised by the literacy of the workers. She explains the absence of a labourmovement among them by the fact, that the majority of this labour force are still women. These studies of the evolution of the silk weavers during the second half of the 19th century suggest, that Villermé's report, in spite of his linguistic difficulties, was rather realistic.

\section{Footnotes}

1 Coleman, W., Death is a social disease, Madison 1982, is the best monograph on Villermé.

2 Ackerknecht, E. H., Hygiene in France 1815-48, Bull. Hist. Med.22: $117 \mathrm{ff.}, 1948$.

3 Villermé, vol. I, P. 4i18-436.

4 ib. P. 418.

5 ib. P. 420 .

6 ib. P. 423 .

7 ib. P. 426.

8 ib. P. 432.

9 ib. P. 434.

10 ib. P. 428.

12 ib. P. 356.

13 ib. P. 362.

14 ib. P. 394.

15 ib. P. 383.

16 ib. P. 393. 
17 ib. P. 390.

18 ib. P. 76.

19 ib. P. 77.

20 ib. P. 85.

21 ib. P. 103.

22 ib. P. 105.

23 ib. P. 110.

24 ib. P.113.

24aib. P. 31.

25 ib. P. 24.

26 ib. P. 28.

27 ib. P. 35.

28 ib. P. 36.

29 ib. P. 44.

30 ib. P. 48.

31 ib.P. 58.

32 ib. P. 348 .

33 ib. P. 35.

33a For Villermé on child labor see also, his letters to Quetelet. E. H. Ackerknecht, Villermé and Quetelet, Bull. hist. Med.26: 317-329, 1932.

34 Villermé, P.371.

35 ib.P. 390.

36 Villermé I, P. II

37 Gruner, E., Der Arbeiter in der Schweiz im 19. Jahrhundert. Bern 1980, P. 183.

37a Steiger, E., Geschichte der Frauenarbeit in Zürich. Zürich 1958, P. 168.

38 Renschler, R., Linkspresse in ZH. Zürich 1967, P. 120.

38a For child labor in Zurich see also Largiadère, A., Geschichte von Zürich. Erlenbach, vol. II, P. 182-185.

39 Müller, F., Seide. Zürich 1913, P. 120.

40 Largiadère II, P. 104.

41 Largiadère I.c. P. 106.

42 Villermé I.c. I, P. 444.

44 Lorenz, Jak., Heimarbeit. Basel 1909, P. 19.

45 Largiadère II, P. 104.

46 Meier, Rolf, August Forel.Zürich 1986, P. 145.

47 for Schuler see Buess, H., Praxis 47: 1236-1239, 1958.

48 Anrooy, P. 160. 


\section{Summary}

Überraschenderweise enthält das klassische Werk von Villermé (1782-1863) über die Lage der Textilarbeiter in Frankreich ein Kapitel über die Zürcher Textilarbeit, das hier nebst den Kapiteln über Lyon, Lille und Mulhouse zu Vergleichszwecken referiert wird. Einiges kann zur Erklärung dieser Merkwürdigkeit beitragen: Die Konkurrenzsituation zwischen Frankreich und Zürich in der Seidenindustrie; Zürich als Vorbild in Villermés Augen. Das Verhältnis zur Realität von Villermés Zürich-Bericht wird untersucht und der Vorwurf der Schönfärberei zurückgewisen.

Prof. Dr. med. Dr.h.c. mult. Erwin H. Ackerknecht

Ottikerstraße 42

CH-8006 Zürich 